\title{
Características nutricionales de los escolares afrodescendientes de la costa pacífica Colombiana
}

\author{
Nutritional characteristics of \\ afro-descendant schoolchildren of \\ Colombian pacific southwest coast
}

\begin{abstract}
This paper provides a current diagnosis on the nutritional status of schoolchildren of pacific coast of Cauca in Colombia. A secondary analysis of publicly available anthropometric data was performed. BMI/Age and $\mathrm{H} /$ Age indices, nutritional classification and their association with gender, ethnicity, age and geographical area of 6793 students aged 5 to 18 years of the municipalities of Guapi, Lopez de Micay and Timbiquí were determined. Normality was the prevalent nutritional status in the three municipalities for schoolchildren of all ages according to BMI and height $(65.7 \%$ and $59.3 \%$, respectively); Guapi was found to be the main contributor. There was no significant differences of BMI and region among males and females. Adolescents between 12 and 14 years old had percentages of stunting significantly higher than other age ranges. Results highlight the need to identify, measure and monitor indicators of health, food habits and sociodemographic aspects of schoolchildren in this region to strictly explore whether Colombian black children fit WHO patterns and to provide specific information for successful national nutrition policy planning for this population.

Key words: ethnic groups, body mass index, stunting, nutritional status, child development.
\end{abstract}

Rubén Andrés Ortega B. (1) Néstor Raúl Basto T. (2) Diana María Chito T. (3)

1) Programa de Administración de Empresas Agropecuarias Fundación Universitaria de Popayán. Popayán, Colombia. (2) Escuela de Ciencias Agrícolas Pecuarias y del Medio Ambiente. Universidad Nacional Abierta y a Distancia. Popayán, Colombia. (3) Departamento de Química, Edificio de los laboratorios. Universidad del Cauca., Sector Tulcán. Popayán, Colombia.

Corresponding Author: Rubén Andrés Ortega Bonilla Fundación Universitaria de Popayán, Programa de Administración de Empresas Agropecuarias, Sede Campestre Los Robles Popayán Km. 8 vía al sur Telephone: +573205633547 E-mail: andres.ortega@docente.fup.edu.co

Este trabajo fue recibido el 18 de Noviembre de 2015 y aceptado para ser publicado el 2 de Julio de 2016.

\section{INTRODUCTION}

On the basis of the most recent Colombian National Survey of Nutritional Status, ENSIN 2010 (1), the Pacific coast is the region with the highest percentages of stunting $(18,3 \%)$, global malnutrition (4,0\%) and excess weight (29,3\%) with a prevalence mainly in children. Four departments make up this region: Chocó, Valle del Cauca, Nariño and Cauca, being this last the main contributor to the statistics. This fact is associated to a strong influence of armed conflict on resident population and limited access to food as consequence of the poor road infrastructure of communication with the rest of country. Among the sociodemographic features of its population highlight ethnicity, above $90 \%$ population is Afro-Colombian (2).

Over years, several investigations have illustrated the marked differences between the nutritional aspects of white and black children; in general, white children have exhibited better indicators than black (3) and this fact could encourage risks factors for health in adulthood of the minority group. Chronic diseases are associated with racial/ethnic disparities. Black children have a prevalence of risk for multiple health conditions (asthma, hearing impairment, visual impairment and join/bone/muscle problems) significantly higher than white (4). In addition, it is important to consider the influence of geographic disparities of their places of residence and sociodemographic factors. Historically, Afro people have been forced to survive in areas with extreme climatic conditions (5). From a nutritional point of view, such conditions limit the access to primary nutrients and let to the population vulnerable to multiple risks from early ages (6).

On the other hand, the infant mortality rate is an aspect that discriminates the nutritional status of whites and blacks. Findings suggest that mortality rate of black infants tends to be double than of white (7). 
Pacific coast of the Cauca department is an area physically disconnected from each other and politically neglected, but with a great natural richness and an immense diversity of species (8). Ironically, the same natural resources had become a particular target of national and international economic interventions. Moreover, in the last two decades, guerrillas, paramilitary forces or large agribusiness have exploited and/or invaded most of this region (2). The above leads to predict that this region will remain poor and economically underdeveloped, and as result, with a population nutritionally affected.

Despite national nutritional statistics in Colombia have been performed in 2005 and 2010 they do not characterize the whole population of the 32 departments due to high economic costs and long time needed for this purpose. Hence, to date there are no scientific reports in the literature on the nutritional status disaggregated by geographical regions. This may be a disadvantage at the time of design and implement public policies to try reducing the rates of malnutrition, as well as, this would contribute to isolate the Afro-Colombian community of the rest of country. The aim of this study was to assess the nutritional state of school-age children residents in Guapi, Lopez de Micay and Timbiquí, depressed municipalities of the Pacific coast of the Department of Cauca, in order to explore racial/ethnic differences from public data collected by PANES (Food and Nutrition School Programme).

\section{SUBJECTS AND METHODS} Participants

We used the reports of health survey 2014 of PANES programme performed in the Pacific Coast of the department of Cauca (Colombia). This is a governmental programme that develops projects with school population in order to strengthen school restaurants and food safety. A well-trained staff of technicians paid by PANES Programme collected students' growth parameters of schoolchildren aged between 5 and 18 years enrolled from first grade of elementary school to eleven grade of high school in fifteen educational institutions of the only three municipalities that makes up Pacific coast of Cauca: Guapi, Lopez de Micay and Timbiquí. All parents of the infants and the chancellors of the schools involved were informed about the purpose, procedures, and privacy of the measurements and signed an informed consent. Training about taking proper measurements of weight and height was given to technicians by a contracted expert in nutrition and dietetics. The indicators reported were: height, weight, gender, ethnicity and area of residence; subjects were categorized as urban if they lived in the municipal capital. Body Mass Index (BMI) was calculated as weight $(\mathrm{kg})$, divided by height $(m)$ squared. Height-for-age (H/A) and BMI-for-age (BMI/A) were indicators assessed in schoolchildren according to standard classification proposed by World Health Organization (9). The study did not require ethics review, since this is a secondary analysis of publicly available data. In fact, analysis with data from PANES database have recently been published $(10,11)$.

\section{Data analysis}

Means and standard deviations of height, weight and frequencies (age, gender, ethnic, BMI and municipalities) were calculated. ANOVA test with alpha 0,05 was used to compare the differences in mean values of age, weight and height and frequency values of ethnicity and geographical area in respect to gender. Pearson correlations were fixed between some variables with a significance level $<0,01$. Associations among $\mathrm{BMI}$ and gender, age, origin and ethnicity were established by means of cross-tabs using Chi square with a confidence interval of $95 \%$. Results are considered statistically significant at level $<0,05$. Also, the influence of variables of interest on studied parameters was explored using multiple regression models.

Standard deviation scores (SDS) for height adjusted for ages were estimated from individual data. "Short" children (SDS height below -1) or "tall" children (SDS height above +1) was based on the national reference data for height of WHO by applying of AnthroPlus software (12).

Statistical analyses were performed with SPSS v.20 software.

\section{RESULTS}

Characteristics of schoolchildren participants

Descriptive statistics for independent and control variables in this study are presented in table 1 . Almost one-third $(34,1 \%)$ of sample is composed by participants between the ages of 5 and 8 years. Most of the sample were men $(53,2 \%)$ and nearly half of sample $(44,9 \%)$ were from the municipality located most northerly on the pacific coast of Cauca, Lopez de Micay. Over $95 \%$ of sampled population was Afro and approximately $60 \%$ were schoolchildren residents in rural areas of the municipalities evaluated. Normality was above $50 \%$, followed by risk of thinness and risk of stunting according to $\mathrm{BMI}$ and height/A, respectively.

As shown in table 2, male gender had significantly $(p=0,005)$ higher percentages of participation than female at different age ranges analysed; mainly in schoolchildren between 5 and 8 years old. In addition, averages of weight and height in men were significantly higher than women. No significant differences for BMI and area by gender were found. However, height/A indicator showed higher contributions in the three nutritional status of male schoolchildren than female; as well as, male population from rural areas significantly predominated over female.

\section{Indicators of nutritional status}

Associations between independent variables and nutritional indicators are gathered in tables 3 and 4. BMI/A classification by region showed that normal status $(63,1 \%)$ prevailed in male schoolchildren (55,5\%) living in urban area $(57,7 \%)$ of Guapi being significantly higher the population between 5 and 8 years $(33,0 \%)$. In Lopez de Micay and Timbiquí, the prevalence followed a similar tendency; in this case, sample was characterized by being totally Afro. The youngest $(31,8 \%)$ and inhabitants of rural areas (46,9\%) were shown to be the schoolchildren predominant; while Timbiquí presented contributions significantly higher from black men.

Regarding to other nutritional status according BMI, table 3 shows that overweight and risk of thinness status were more representative in Guapi (9,5\% and $16,8 \%$, respectively) and in Lopez de Micay (14,1\% and 12,1\%, respectively).

The nutritional classification found for the studied population from height/A data (table 4) establishes a significantly higher proportion of black boys with ages between 5 and 8 years with normal values than female schoolchildren of other ages. By region, Guapi and Timbiquí reported the percentages of stunting for female statistically lower than men. With respect to age, adolescents between 12 and 14 years old had a contribution significantly higher to that normality. The amount of children grouped with stunting in Lopez de Micay $(73,1 \%)$ 
of rural areas was significantly higher than urban. Sample evaluated in Timbiquí was composed entirely by resident students in rural areas.

By application of multiple regression analysis (stepwise method: $p=0,05$ input and $p=0,10$ output) setting normality and malnutrition according to BMI/age and height/age (yes/ no) as dependents variable and municipality, gender, age range, area and ethnicity as independents variable, models with $\mathrm{R} 2=$ $0,705, R 2=0,198, R 2=0,028$ and $R 2=0,014$, respectively, explained for the exclusion of gender and/or area and ethnicity were achieved (table 5).

\section{DISCUSSION}

The present study provides local data on the prevalence of nutritional status of schoolchildren of the Cauca pacific coast, region of the department of Cauca (Colombia) where Afro ethnicity is concentrated (13). Levels of stunting and overweight $(13,9 \%$ and $12,2 \%)$ estimated here were lower than national average for children and adolescents of the Colombian Pacific (16,3\% and 13,2\%) (1); whilst current prevalence of thinness and obesity reached to be $25 \%(5,0 \%$ and 3,4\%) higher than reported by ENSIN 2010 (2,2\% and $3,0 \%)$. These findings confirm that after four years the nor-

\section{TABLE 1}

Descriptive analysis results for variables determined among schoolchildren of the pacific coast of the department of Cauca.

Variable

Age (years)

Average $\pm S D^{a}$

Median (IQR)

By range, n (\%)

5-8

9-11

12-14

15-18

Gender, n (\%)

Male

Ethnicity, n (\%)

Afro

Indigenous

Mestizo

Weight (kg)

Average $\pm \mathrm{SD}^{\mathrm{a}}$

Median (IQR) ${ }^{\mathrm{b}}$

Height (cm)

Average $\pm \mathrm{SD}^{\mathrm{a}}$

Median (IQR) ${ }^{b}$

BMIc-for-age classification, n (\%)

Obesity

Overweight

Normal

Risk of thinness

Thinness

Height-for-age, n (\%)

Normal

Risk of stunting

Stunted

Municipality, n (\%)

Guapi

Lopez de Micay

Timbiquí

Area, n (\%)

Urban

Rural
Sample $(n=6$ 793)

$10,5 \pm 3,5$

$10,0(5,0-18,0)$

$2319(34,1)$

$1864(27,4)$

$1528(22,5)$

$1082(15,9)$

$3611(53,2)$

$6523(96,1)$

$22(0,3)$

$248(3,7)$

$35,2 \pm 13,9$

$32,0(12,0-99,0)$

$1,38 \pm 0,18$

$1,37(0,95-1,97)$

$230(3,4)$

$828(12,2)$

$4461(65,7)$

$936(13,2)$

$338(5,0)$

$4029(59,3)$

$1818(26,8)$

$946(13,9)$

$2137(31,5)$

$3049(44,9)$

$1607(23,7)$

$2725(40,1)$

$4068(60,1)$

\footnotetext{
a SD: Standard deviation; ${ }^{\mathrm{b}}$ IQR: Interquartile range; cBMI: Body Mass Index.
} 
mality continues being the predominant nutritional condition according to both BMI-for-age and height-for-age (table 1). This situation may be explained by an improvement of conditions of food security or feeding practices or access to health services or increased coverage of food security programs. However, BMI/A analysis evidence a trend to the increasing of malnutrition in this region, especially for children between 5 and 8 years of age. It is important to recognize that this population could quickly fall into moderate or severe malnutrition in the event that take place prolonged periods of time with an inadequate nutrition (14). This fact should be timely intervened given that could be a tendency to increase the clinic risks in adulthood.

Stunting is a linear growth retardation which results from inadequate intake of food over a long period of time, micronutrient deficiencies, exposure to environmental pathogens and poor sanitation, suboptimal feeding practices, poor prenatal nutrition causing intrauterine growth retardation, impaired growth plate regulation, and disruption in the gut microbiota and immune system (15). Acosta and Meisel analyzed the evolution of height among Colombians of different ethnic groups born between 1965 and 1990 (13). Their findings reveal that Afro-Colombians were the tallest group. These observations are consistent with the results reported here in Guapi, Lopez de Micay and Timbiquí (see table 4). Under this result and considering the real survival conditions of the population of these regions which evidence the historical racial differences in socioeconomic variables and disparities in nutritional outcomes respect to white population (3), one could think that WHO cut-offs are not the best references for these target samples.

The independence of normal status of gender and the dependence of malnutrition of municipality and age ranges in terms of BMI/A were verified through multiple regression analysis (table 5). Likewise, normal growth was associated to municipality where were residing the children, gender

\section{TABLE 2}

Independent variables and growth indicators of schoolchildren living in Cauca pacific coast discriminated by gender.

Variable

Age ranges (years), $\mathrm{n}(\%)$

5-8

9-11

$12-14$

$15-18$

Ethnicity, n (\%)

Afro

Indigenous

Mestizo

Weight (kg)

Average $\pm S D^{a}$

Height (m)

Average $\pm \mathrm{SD}^{\mathrm{a}}$

BMIb-for-age classification, n (\%)

Obesity

Overweight

Normal

Risk of thinness

Thinness

Height-for-age, n (\%)

Normal

Risk of stunting

Stunted

Municipality, n (\%)

Guapi

Lopez de Micay

Timbiquí

Area, n(\%)

\section{Male}

$(n=3$ 611)

\author{
$1174(50,6)$ \\ $1007(54,1)$ \\ $809(52,9)$ \\ $621(57,4)$ \\ $3473(53,2)$ \\ $12(54,5)$ \\ $126(50,8)$
}

$35,5(14,1)$

$1,39(0,19)$

$123(53,5)$

$436(52,7)$

$2347(52,6)$

$518(55,3)$

$187(55,3)$

$2075(51,5)$

$1019(56,1)$

$517(54,7)$

$1175(55,0)$

$1579(51,8)$

$857(53,3)$

$1408(51,7)$

$2203(54,2)$
Female

$(n=3$ 182)

0,005

$857(46,0)$

$719(47,1)$

$461(42,6)$

Urban

$3050(46,8)$

$10(45,5)$

$122(49,2)$

$34,9(13,7)$

0,052

$1,37(0,17)$

0,000

0,207

$107(46,5)$

$392(47,3)$

$2114(47,4)$

$418(44,7)$

$151(44,7)$

$1954(48,5)$

0,019

$799(43,9)$

$429(45,3)$

$962(45,0)$

0,084

$1470(48,2)$

$750(46,7)$

0,889

$1317(48,3)$

$1865(45,8)$

aSD: Standard deviation; 'BMI: Body Mass Index. 


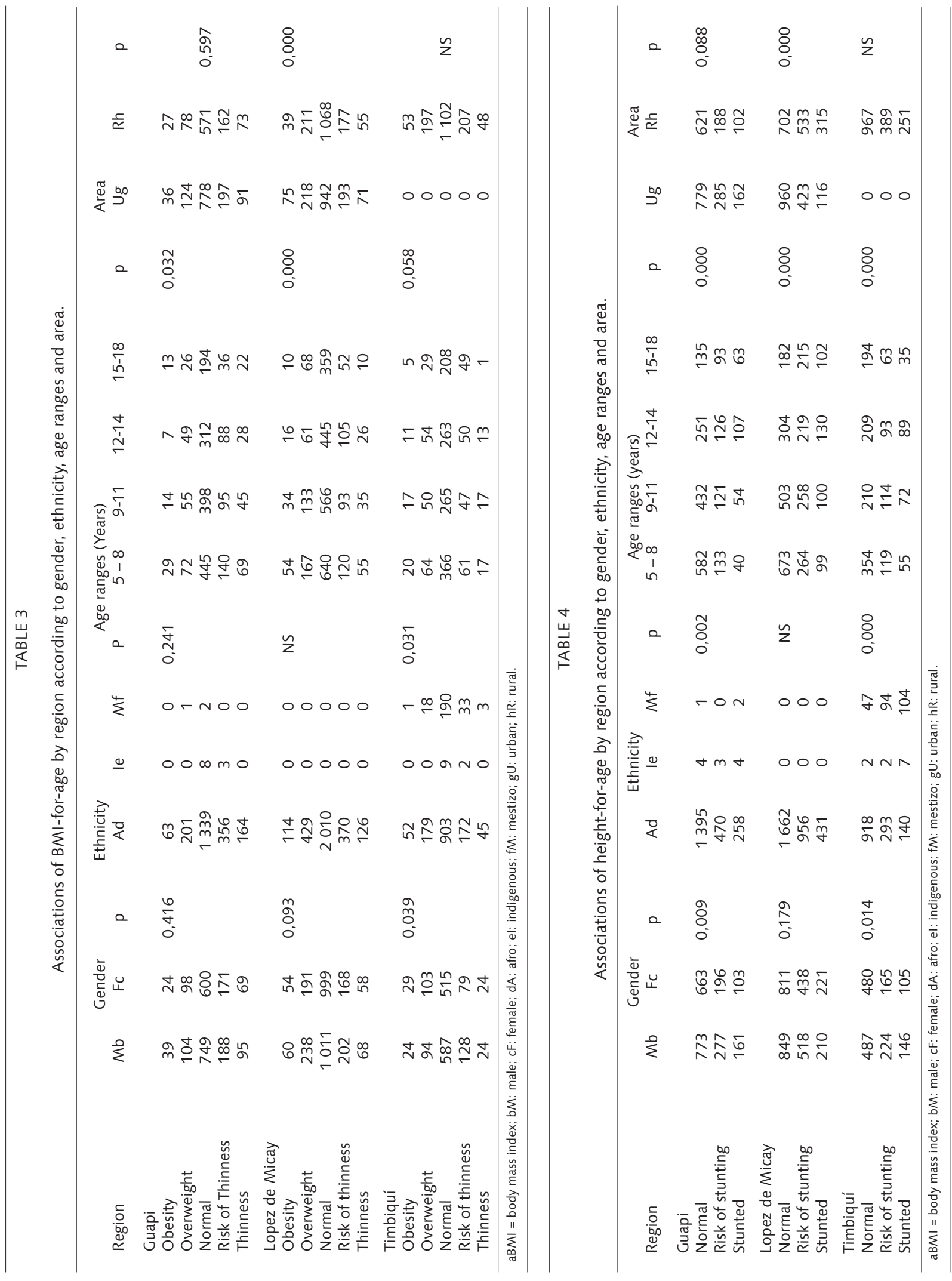


and their age ranges; whilst malnutrition showed significant association with the municipality supporting the existence of marked differences in accessibility of food explained by transport conditions available to each municipality.

We were also interested to distinguish the differences could exist among the mean height of Afro groups with different origin worldwide. We compared the mean height of Afro children from Cauca Pacific coast aged between 2-15 years with reported for black Caribbean and African children living in England (16); Cauca black girls' average height (135,6 $\mathrm{cm}$ ) was slightly above Caribbean (134 cm) and African (131,8 $\mathrm{cm})$ while boys' average $(136,1 \mathrm{~cm})$ was below than that of Caribbean and above African. We could speculate these differences are caused mainly by differences of physical activity and food provision.

Several authors have assessed the impact of living conditions on children's health and nutritional indicators (17). However, ENSIN and PANES surveys did not collected data on sociodemographic variable to broaden the scope of our results. Acosta and Meisel proposed an index of wealth for evaluating socio-economic status from anthropometric data of individuals categorized by ethnic groups in the National Survey of Demography and Health (ENDS, in Spanish) and National Survey of Nutritional Situation (13). This index enabled to extrapolate household income from observable living conditions. It was found that wealth/nutrition was positively correlated with height; individuals at the top of the socio-economic pyramid were taller than those at the bottom, being this, a generalized situation to indigenous, Afro-Colombians and others races.

On the other hand, tendency of growth's indices already reported may also be understood from disparities that exist in the availability of transport among the three municipalities target and their effect on families' access to food. Mining is one of the main economic activities in this area of Pacific coast, but Guapi is the only municipality has three flights a week from Cali (the nearest main city), while arriving to Timbiquí and Lopez de Micay is addressed mainly by boat from Guapi. Hence, no native products become more expensive and inaccessible to general community, especially, the residents of Lopez de Micay and Timbiquí who reside predominantly in rural areas. Not surprisingly, risk of stunting, thinness and risk of thinness in these areas could be correlated with the consequences provoked by the illegal activities and armed conflict which have affected a homogenous and proper distribution of potable water for these families; in addition, its acquisition is limited either by high prices or because its use is prioritized for other activities. In this context, evidence on health disparities by ethnic (involving the risk of diseases and negative effects) (7) may also encourage the levels of malnutrition found in schoolchildren of this geographical region where there is prevalence of Afro.

The most significant contribution that these findings bring to light is the disaggregation of the school nutritional status of

\section{TABLE 5}

The relation between growth indicators according to BMI/A and Height/A and potentially predictor variables.

Independent variables

Model 1. Students in normal nutritional status according to BMI/A Municipality

Age range

Area

Ethnicity

Gender

Model 2. Students in malnutrition nutritional status according to BMI/A

Municipality

Age range

Area

Gender

Ethnicity

Coefficient

$P$

$R^{2}$

0,705

$\begin{array}{ll}2,358 & 0,000 \\ 0,609 & 0,000 \\ 0,254 & 0,000 \\ 0,217 & 0,016 \\ 0,000 & 0,976\end{array}$

Model 3. Students in normal nutritional status according to Height/A

Municipality

Age range

Gender

Area

2,609

0,445

0,000

0,015

0,032

Ethnicity

0,165

$-0,062$

$-0,080$

0,023

$-0,014$

Model 4. Students in malnutrition nutritional status according to Height/A

Municipality

$-0,113$

Age range

$-0,019$

Gender

0,014

0,004

Ethnicity
0,000

0,000

0,987

0,427

0,094

0,198

0,028

0,000

0,000

0,002

0,183

0,385
$-0,001$

0,000

0,313

0,461

0,834

0,952 
Afro region in Cauca (specifically, the municipalities of Guapi, Lopez de Micay and Timbiquí) given that National Surveys of the Nutritional Situation carried out in Colombia in 2005 and 2010 are the only formal reports that estimate the prevalence of the main nutritional problems of the Colombian population, but these are approximations and evidence the necessity to develop specific studies for each one of the departments of the country. BMI and height indicators showed that normal, risk of thinness and risk of stunting are status remaining in black schoolchildren with ages between 5 and 8 years and residents in rural areas. While the prevalence of excess of weight in this area that is insufficiently connected to the rest of the departments is associated to male who reside in Guapi and Lopez de Micay and female in Timbiquí with ages between 5 and 11 years. Results emphasize the need to identify, measure and monitor indicators of health, food habits, health services and sociodemographic aspects of families of schoolchildren target to provide specific information for successful national nutrition policy planning.

\section{Limitations}

The outcomes of this study contribute to enrich the scientific literature worldwide to support the nutritional differences among schoolchildren according to the ethnicity and geographical origin. However, this contribution has several limitations; analyzed variables were limited to those reported by PANES survey. Other variables such as dietary habits, physical activity, medical history, household income, family patterns and transportation were not included in the correlations. This is lacking information that would improve the understanding of findings. Nutritional status was inferred from BMI and height for age only, biochemical or additional anthropometric measurements might offer a wider perspective. Local clinic background does not support strictly the reported here given that public statistics of pandemic or chronic diseases suffered by Cauca population are not available. One final limitation is that the relationships among nutritional status of black schoolchildren residents in Cauca Pacific coast and Buenaventura Coast (seaport on the border area) were not established. These explorations would allow to evidence the impact of life conditions (from a point view of access to water and food, transportation, etc.) on nutritional prevalence of people with genetic similarities whose growth is carried out with similar food patterns.

\section{IMPLICATIONS FOR SCHOOL HEALTH}

A key finding of this study was the height ranges of assessed black children which is in agree with reported for similar population from other countries (16). This is a significant contribution to administrators of schools and politics leaders of these regions to conduct a timely monitoring. In addition, the frequency in physical activity in the schools seems be an important contributor to levels of excess weight which should be checked. Stunting levels had high prevalence in children less 10 years, and may need extra supervision into schools. Thus, school meals should ensure that access to food improves; in this sense, school gardens are important strategies which must be preserved to promote the consumption of healthy foods including fruits and vegetables (18).

\section{RESUMEN}

El presente artículo proporciona un diagnóstico sobre el estado nutricional de los escolares de la costa pacífica del Cauca en Colombia. Se realizó un análisis secundario de datos antropométricos públicos que están disponibles. Se determinaron los índices IMC/edad y talla/edad, la clasificación nutricional y su asociación con el género, etnia, edad y área geográfica de 6793 estudiantes de 5 a 18 años de los municipios de Guapi, López de Micay y Timbiquí. La normalidad fue el estado nutricional prevalente en los tres municipios para escolares de todas las edades de acuerdo al BMI y la talla (65.7\% y $59.3 \%$, respectivamente); Guapi resultó ser el principal contribuyente. No hubo diferencias significativas de IMC y región entre hombres y mujeres. Los adolescentes entre 12 y 14 años tuvieron porcentajes de retraso en el crecimiento significativamente más elevados que los de otros rangos de edad. Los resultados destacan la necesidad de identificar, medir y monitorear los indicadores de salud, hábitos alimentarios y aspectos sociodemográficos de los escolares en esta región para explorar si los niños afrodescendientes se ajustan a los patrones de la OMS y para proveer información específica para un exitoso planeamiento de una política de nutrición nacional para esta población.

Palabras clave: grupos étnicos, índice de masa corporal, retraso de crecimiento, estado nutricional, desarrollo infantil.

Acknowledgements: Authors thank to Programa de Alimentación y Nutrición Escolar-PANES of the Government of Cauca (Colombia) for providing us the databases used in this study.

\section{REFERENCES}

1. Centeno $Z$, Heredia $A P$, Ocampo $P$, Forero $Y$, Sarmiento $O$, Alvarez M, Estrada A, Samper B, Gempeler J, Rodríguez $M$. National Survey on the Nutritional Situation in Colombia 2010. 1st edn. Bogotá, Colombian Family Welfare Institute; 2011, p. 1-510.

2. Asher K, Ojeda D. Producing nature and making the state: Ordenamiento territorial in the Pacific lowlands of Colombia, Geoforum 2009; 40(3):292-302.

3. Reis M. Differences in nutritional outcomes between Brazilian white and black children, Econ Hum Biol. 2012; 10(2):174-88.

4. Kitsantas P, Kornides ML, Cantiello J, Wu H. Chronic physical health conditions among children of different racial/ ethnic backgrounds, Public Health 2013; 127(6):546-53.

5. Grueso L, Rosero C, Escobar A. The Process of Black Community Organizing in the Southern Pacific Coast Region of Colombia. Perspectives on Las Américas: A Reader in Culture, History, \& Representation. Blackwell Publishers Ltd, 2008, p. 430-47.

6. Vanos JK. Children's health and vulnerability in outdoor microclimates: A comprehensive review, Environ Int. 2015; 76(0):1-15.

7. Mehta NK, Lee $H$, Ylitalo KR. Child health in the United States: Recent trends in racial/ethnic disparities, Soc Sci Med. 2013; 95(0):6-15.

8. Asher K. Mobilizing the discourses of sustainable economic development and biodiversity conservation in the pacific lowlands of colombia, strategies: J Theory Culture Politics 2000; 13(1):111-25.

9. World Health Organization. Global database on body mass index, Geneve, WHO, 2014.

10. Ortega $A$, Chito $D$. Assessment of nutritional status of school population of argelia, colombia, Rev Salud Publica 2014; 16(4):547-59.

11. Ortega-Bonilla RA, Chito-Trujillo DM. Prevalence of overweight and obesity in schoolchildren of a rural Colombian 
community, Rev Esp Nutr Hum Diet. 2015; 19:212-20.

12. World Health Organization. Application tools: WHO anthroplus software, Geneve, WHO, 2014.

13. Acosta K, Meisel A. Anthropometric measurements by ethnicity in Colombia, 1965-1990, Econ Hum Biol. 2013; 11(4):416-25.

14. Bhagowalia $P$, Chen SE, Masters WA. Effects and determinants of mild underweight among preschool children across countries and over time, Econ Hum Biol. 2011; 9(1):66-77.

15. Richard SA, Black RE, Gilman RH, Guerrant RL, Kang G, Lanata CF, Mølbak K, Rasmussen ZA, Sack RB, ValentinerBranth $P$, Checkley $W$, Infection $C$, Network M. Wasting is associated with stunting in early childhood. J Nutr. 2012;
142(7):1291-6.

16. Weichselbaum E, Buttriss JL. Diet, nutrition and schoolchildren: An update, 2014; 39(1):9-73.

17. Linnemayr S, Alderman H, Ka A. Determinants of malnutrition in Senegal: Individual, household, community variables, and their interaction, Econ Hum Biol. 2008; 6(2):252-63.

18. Intersectoral Committee on Food Safety and Nutrition of Cauca, Government of Cauca, Food and School Nutrition Programme, Department of Agricultural Development and Mining, Plan for Food Safety and Nutrition for the Department of Cauca. Cauca without Hunger 2009-2018. Colombia, 2009. 